\title{
Association between musculoskeletal symptoms and perceived stress in public servants of a Federal University in the South of Brazil
}

\author{
Associação entre sintomas osteomusculares e estresse percebido em servidores públicos de \\ uma Universidade Federal do Sul do Brasil
}

Letícia Maria da Silva Almeida', Samuel de Carvalho Dumith²

DOI 10.5935/2595-0118.20180004

\section{ABSTRACT}

BACKGROUND AND OBJECTIVES: In view of the high prevalence of pain complaints among workers in the country and their consequences in the quality of life and work, the objective of this study was to investigate the association between the perceived stress and the presence of musculoskeletal symptoms among public servants of the Federal University of Rio Grande.

METHODS: Observational, transversal and quantitative study. The survey population comprised all active servants in the second semester of 2016 in any campuses of the Federal University of Rio Grande. Participants received a digital invitation to participate in the survey containing a link that would lead to the questionnaire generated by Google Docs. The questionnaire was composed of questions on demographic data, and two standardized instruments: the Nordic Musculoskeletal Questionnaire and the Perceived Stress Scale. The descriptive analysis was done by absolute and relative frequency. For the bivariate analysis, it was used the Fisher's Exact test. P values were reported for the linear trend test on associations between stress and pain.

RESULTS: Of the total number of eligible servants $(\mathrm{n}=717)$, $36.6 \%$ participated in the study. The spine was the most reported area of the body with pain symptoms in the last 12 months, and in the last seven days. The least prevalent region of pain was hips / thighs. It was observed that the greater the perceived stress, the greater was the prevalence of musculoskeletal symptoms. It was observed a statistically significant linear trend in almost all assessed anatomic regions.

CONCLUSION: There was a high prevalence of musculoskeletal symptoms in the analyzed population, as well as a strong association between the perceived stress and the presence of these symptoms.

Keywords: Musculoskeletal pain, Psychological stress, Universities, Workers.

1. Universidade Federal do Rio Grande, Faculdade de Medicina, Rio Grande, RS, Brasil. 2. Universidade Federal de Rio Grande, Faculdade de Medicina, Programa de Pós-Graduaçâo em Saúde Pública. Rio Grande, RS, Brasil.

Submitted in August 26, 2017

Accepted for publication in January 05, 2018.

Conflict of interests: none - Sponsoring sources: none.

Correspondence to:

Rua Visconde de Paranaguá 102 - Centro - Campi Saúde

96203-900 Rio Grande, RS, Brasil.

E-mail: leticiamsalmeida@hotmail.com

(c) Sociedade Brasileira para o Estudo da Dor

\section{RESUMO}

JUSTIFICATIVA E OBJETIVOS: Diante da alta prevalência das queixas de dor entre os trabalhadores no país e suas consequências para qualidade de vida e no trabalho. $\mathrm{O}$ objetivo deste estudo foi investigar a associaçáo entre o estresse percebido e a presença de sintomas osteomusculares entre servidores públicos da Universidade Federal do Rio Grande.

MÉTODOS: Estudo observacional, transversal e quantitativo. O público da pesquisa foi todos os servidores efetivos que estavam em atividade no segundo semestre de 2016 de qualquer dos campi da Universidade Federal do Rio Grande. Os participantes receberam, por via digital, um convite para participar da pesquisa contendo um link que remetia ao questionário, gerado pelo Google Docs. O questionário foi composto por perguntas que inquiriam dados demográficos e duas avaliaçóes padronizadas: Nordic Musculoskeletal Questionnaire e Escala de Estresse Percebido. A análise descritiva tratou-se da frequência absoluta e relativa. Para análise bivariada, utilizou-se o Exato de Fisher. Foram reportados os valores p para o teste de tendência linear nas associaçôes entre o estresse e a dor.

RESULTADOS: Participaram do estudo 36,6\% do número total dos servidores $(\mathrm{n}=717)$. A região das costas foi a mais prevalente de dor quanto aos sintomas nos últimos 12 meses, e nos últimos sete dias. A região menos prevalente foi quadril/coxas. Verificou-se que quanto maior o estresse percebido, maior foi a prevalência de sintomas osteomusculares. Observou-se tendência linear com significância estatística em quase todas as regiôes anatômicas analisadas.

CONCLUSÃO: Constatou-se elevada prevalência de sintomas osteomusculares na população estudada, além da forte associação entre o estresse percebido e a presença destes sintomas.

Descritores: Dor osteomuscular, Estresse psicológico, Trabalhadores, Universidade.

\section{INTRODUCTION}

Pain is pointed out as one of the most common complaints among the reasons for seeking care in healthcare services and one of the reasons for self-medication in the country ${ }^{1,2}$. The prevalence of chronic pain in the general population, investigated in a multicenter study, with 42,249 people older than 18 years, in 17 countries, was $38.4 \%{ }^{3}$. Another study, which assessed 46,394 people in 15 European countries and Israel, found that $19 \%$ had 
moderate or severe pain lasting at least six months, had pain in the last month and had pain at least twice a week ${ }^{4}$.

Several factors are related to the triggering, development, and maintenance of musculoskeletal pain. When it comes to acute pain, it is understood as a response to the stimuli on the surface of the skin, since it is a physiological pain that triggers a protective reaction, such as the withdrawal reflex to stop the exposure to noxious stimulus 5 . However, the persistent pain picture cannot be considered an adaptive response when nociceptive afferent stimuli induce changes leading to the deleterious effects of chronic pain ${ }^{5}$. Individual factors (age, gender, life habits), sociodemographic, psychosocial, physical and organizational factors are mentioned $^{6}$. In addition, the perception of stress and the relation with mental health are indicated as important impact factors on pain in many systems of the human body ${ }^{6}$.

The relationship between the psychosocial aspects of work and musculoskeletal symptoms are studied in several professions ${ }^{7}$. It is recognized that some professional categories are more exposed to the onset of these symptoms ${ }^{8,9}$. Psychosocial work factors have been pointed out for many years because they are related to a large amount of health complaints ${ }^{10}$. Occupational stress can also affect and promote the prevalence of musculoskeletal disorders and symptoms ${ }^{10}$.

It is known that stress leads to symptoms in the body, similar to the reactions caused by toxic-chemical substances. This picture is associated with sensations of discomfort that disturb the homeostasis of the human body ${ }^{11}$. The stages of stress evolution, such as alarm, resistance and adaptation, and finally the exhaustion in most severe and persistent situations are also mentioned ${ }^{11}$.

Musculoskeletal pain is reported in several studies with teachers as a relevant health problem ${ }^{12-14}$. The diseases caused by injuries to the musculoskeletal system appear as the main causes of leave of absence and occupational diseases in this category ${ }^{8}$. It is also a contributing factor in mental disorders and increase of absenteeism resulting in countless consequences, such as cost increase in the economy around the world ${ }^{15,16}$.

The high prevalence of pain in the population, the high costs imposed on society, insurance companies and healthcare services, as well as the negative impact on the daily activities of those who live with such experience, put it as a public health problem² . Musculoskeletal symptoms are important causes of absenteeism, and in Brazil, it is the second most prevalent health problem to receive social benefits for temporary and permanent disability $^{17}$. Over the last decade, Social Security numbers indicate that among the most prevalent diagnostic groups of sick benefit benefits are musculoskeletal diseases ${ }^{18}$.

The objective of this study was to investigate the association between the presence of musculoskeletal symptoms and the perceived stress among public servants in the extreme south of Brazil. The hypothesis of the study was based on the fact that adverse life events can trigger central sensitization and aggravate the impact of biological stress systems dysfunction on chronic pain.

\section{METHODS}

This study was cross-sectional, observational, with a quantitative approach. The inclusion criteria were to be an active public servant, that is, to work as an administrative technician and/or teacher at the Federal University of Rio Grande (FURG), in the second half of 2016 and work on the FURG campuses. FURG has campuses in the cities of Rio Grande (Carreiros Campus and Health Campus), Santa Vitória do Palmar, Santo Antônio da Patrulha, and São Lourenço do Sul. As exclusion criterion, the civil servant should be on leave of absence.

There was no calculation of sample size since all the institution's servants were eligible and were invited to participate in the study. The survey was of the census type, and the sample was not by convenience.

The data collection was from October to November 2016. All eligible employees received an individual invitation to participate in the survey, via the university system, and by e-mail. In addition, the university staff was briefed on the survey by a post on the news page of the FURG website. The invitation had a link to the questionnaire used in the survey. This questionnaire was generated by Google Docs and was answered on the computer, only needing an internet connection to open and send. Before answering the questionnaire, teachers had to indicate that they agreed to participate in the study. No personal information as the name or school registration number was collected, keeping the answers anonymous. The average time to fully complete the questionnaire was 5 to 7 minutes.

The questionnaire was composed of blocks of questions. The first with demographic data including gender, age group, time of work, institute and function in the university. The second block was composed by the Nordic Musculoskeletal Questionnaire (NMQ) and the third block consisting of the Perceived Stress Scale (PSS).

The NMQ is a standardized, self-applied instrument, already validated in the country and developed with the intention to standardize the measurement of symptoms reported ${ }^{19,20}$. The authors of this questionnaire do not indicate it as the base for clinical diagnosis, but to identify musculoskeletal disorders and, therefore, be an important instrument of diagnosis of the work environment to elaborate prevention measures ${ }^{19}$. The instrument consists of binary choices referring to the occurrence of symptoms in last the 12 months and in the seven preceding days, in nine anatomical regions and the report of leave of absence of routine activities in the last year ${ }^{20}$. The anatomical regions surveyed are the neck, shoulders, back (upper part), elbows, wrists/ hands, back (lower) hips/thighs, knees and ankles/feet.

The main exposure variable in this study was stress, which was associated with musculoskeletal symptoms, mainly muscle pain in different anatomical regions. The Perceived Stress Scale, also called PSS, was used to assess stress. It consists of a general scale that can be used with different age groups, already translated into Portuguese and validated in Brazil ${ }^{21}$. Its objective is to measure the perceived stress, so it evaluates the degree in which the individuals perceive situations as stressing ones ${ }^{22}$. It is composed of 14 questions in simple language that use the following answers as options: (zero) never; (1) almost never; (2) sometimes; (3) almost always or (4) always ${ }^{21}$. The PSS scores are obtained by the inversion (zero $=4$, $1=3,2=2,3=1$ ) of the scores of the seven positive items (items 4 , $5,6,7,9,10$ and 13), and then by summing all the 14 items ${ }^{22}$. 
For the analysis of the scores of this questionnaire, the results were divided into quartiles, being the first quartile the group with lesser exposure to stress and the last quartile, greater exposure.

The study was approved by the Committee on Ethics for Research in the Health Area (CEPAS) of the Federal University of Rio Grande (FURG) under number 72/2015 (CAAE: 48819115.1.0000.5324).

\section{Statistical analysis}

The answers were exported to an Excel file and later transferred to the statistical package Stata, version 11.2, where data cleansing, variable creation, and data analysis were performed. The absolute and relative frequency of variables were applied for the descriptive analysis. Fisher's Exact test was used for the bivariate analysis. $p$ values for the linear trend test in the associations between stress and pain were reported. The statistical significance level used was $5 \%$ for two-tailed tests. It is worth to mention that interactions

Table 1. Description of the sample of teachers and technicians of the Federal University of Rio Grande, Rio Grande, RS, 2016 ( $n=717)$

\begin{tabular}{lcccc}
\hline Variables & $\mathrm{n}$ & $\%$ & $\begin{array}{c}\text { Stress } \\
(\%)\end{array}$ & $\mathrm{p}$ value \\
\hline $\begin{array}{l}\text { Gender } \\
\quad \text { Female }\end{array}$ & 430 & 60.0 & 21.8 & 0.06 \\
$\quad$ Male & 287 & 40.0 & 15.8 & \\
Age group (years) & & & & 0.71 \\
20-29 & 73 & 10.1 & 18.3 & \\
30-39 & 282 & 39.1 & 21.7 & \\
40-49 & 191 & 26.5 & 19.2 & \\
$50-69$ & 175 & 18.3 & 17.2 & \\
Position & & & & 0.92 \\
$\quad$ Teacher & 312 & 43.5 & 20.1 & \\
Technician & 393 & 54.7 & 19.6 & \\
$\quad$ Both & 13 & 1.8 & 10.0 & \\
Working in the & & & & 0.30 \\
institution (years) & & & & \\
Up to 4 & 285 & 39.6 & 21.6 & \\
5 to 9 & 172 & 23.9 & 21.0 & \\
$\geq 10$ & 263 & 36.5 & 16.6 & \\
\hline
\end{tabular}

in the associations between pain and stress were tested for the variables gender, age group, position and time of work in the institution. When the $\mathrm{p}$ value of the interaction test was lower than 0.10 , the results were duly reported in the text.

\section{RESULTS}

A total of 717 public servants of FURG, which represents $36.6 \%$ of the total number of servants (1960), answered the questionnaire. Most of the participants were female $(60 \%)$ with ages between 30 and 49 years $(65.6 \%)$, with the position of University technician (54.7\%) and working for less than 10 years in the institution (63.5\%) (Table 1). There was no significant statistical correlation between these variables and the perceived stress. The average of the stress score was $42.8 \pm 3.2$, varying from 31 to 53 points, with a median of 43 .

Table 2 shows the data referring to the presence of the musculoskeletal symptoms assessed by the NMQ and its distribution in the different anatomical regions surveyed in this study. These items were described in the last 12 months and in the last seven days. Data on those subjects who had the need to seek health professionals help or who reported impairment to carry an activity were also reported. The back region was the most prevalent for pain symptoms in the last 12 months, and $55.7 \%$ in the lower back and $54.1 \%$ in the upper part. The region with lesser prevalence was the hip/thigh $(24.3 \%)$. In terms of pain symptoms in last the seven days, the anatomical region most pointed as the cause of musculoskeletal symptoms remained to be the lower back (33.2\%) and less pointed the hip/thigh (13.7\%).

Still on table 2, with regard to preventing the performance of any activity, the region most cited was also the back, the lower part $(22.2 \%)$ and the less reported was the hip/thigh (7.6\%). And, as the reason to seek a health professional, the most indicated anatomical region continued to be the back, the lower part $(29.0 \%)$ and the less reported was ankles/feet (12.0\%). Most of the sample reported musculoskeletal symptoms in at least one region assessed in the last year (85.6\%), being slightly less frequent concerning the last seven days $(70.4 \%)$. Almost half of the servants had some kind of impairment in their activities as a result of these symptoms in at least one region (45.7\%), and more than half had to seek a health professional due to this pain $(58.0 \%)$.

Table 2. Distribution of musculoskeletal symptoms by anatomical region in teachers and technicians of the Federal University of Rio Grande, Rio Grande, RS, $2016(n=717)$

\begin{tabular}{|c|c|c|c|c|}
\hline Anatomical regions & $\begin{array}{c}\text { Pain in the last } 12 \\
\text { months (\%) }\end{array}$ & $\begin{array}{c}\text { Prevented any } \\
\text { activity (\%) }\end{array}$ & $\begin{array}{c}\text { Consulted a } \\
\text { professional (\%) }\end{array}$ & $\begin{array}{l}\text { Pain in the last } \\
\text { seven days (\%) }\end{array}$ \\
\hline Neck & 49.9 & 13.4 & 24.9 & 31.9 \\
\hline Shoulders & 51.3 & 15.3 & 26.6 & 31.7 \\
\hline Back (upper part) & 54.1 & 15.4 & 26.9 & 31.1 \\
\hline Back (lower part) & 55.7 & 22.2 & 29.0 & 33.2 \\
\hline Wrists/hands & 45.7 & 13.9 & 18.1 & 22.6 \\
\hline Hips/thighs & 24.3 & 7.6 & 12.2 & 13.7 \\
\hline Knees & 32.7 & 12.7 & 16.3 & 18.7 \\
\hline Ankles/feet & 30.5 & 9.2 & 12.0 & 16.2 \\
\hline In some regions above & 85.6 & 45.7 & 58.0 & 70.4 \\
\hline
\end{tabular}


Table 3. Association between musculoskeletal pain, as to anatomical region in the last year, and stress (in quartiles) of teachers and technicians from the Federal University of Rio Grande, Rio Grande, RS, $2016(n=717)$

\begin{tabular}{|c|c|c|c|c|c|c|c|c|c|}
\hline Stress scale in quartile & Neck & Shoulders & $\begin{array}{c}\text { Back } \\
\text { (upper part) }\end{array}$ & $\begin{array}{c}\text { Back (lower } \\
\text { part) }\end{array}$ & $\begin{array}{l}\text { Hand/ } \\
\text { wrist }\end{array}$ & Hip & Knees & Feet & Any region \\
\hline $1^{\text {st }}$ (less stressed) & 46.6 & 48.5 & 47.0 & 44.7 & 43.1 & 21.7 & 29.5 & 27.3 & 81.9 \\
\hline $2^{\text {nd }}$ & 46.5 & 46.2 & 53.5 & 53.9 & 37.9 & 24.1 & 26.8 & 23.2 & 82.3 \\
\hline $3^{\text {rd }}$ & 50.0 & 57.7 & 54.8 & 62.9 & 48.9 & 19.4 & 36.6 & 35.9 & 88.0 \\
\hline $4^{\text {th }}$ (more stressed) & 63.4 & 59.5 & 66.9 & 70.1 & 53.1 & 32.0 & 38.2 & 40.7 & 92.5 \\
\hline $\mathrm{p}$ trend & $<0.01$ & 0.02 & $<0.01$ & $<0.01$ & 0.03 & 0.12 & 0.04 & $<0.01$ & $<0.01$ \\
\hline
\end{tabular}

Table 3 shows the analysis of the association between the reported anatomical regions with the musculoskeletal symptoms and its relation to the perceived stress. The relation between stress and the presence of the reported symptoms in at least one of the assessed regions was also analyzed. It can be observed that for this variable, the higher the perceived stress, the higher was the prevalence of musculoskeletal symptoms $(p<0.01)$. We observed a positive linear association between the level of perceived stress and the presence of symptoms in almost all the analyzed variables, except for the hip region $(\mathrm{p}=0.12)$.

It was found that for the neck and lower back regions, this association with stress was more pronounced in the administrative technicians. The numbers also pointed out that there was a statistically significant linear association only for teachers in the case of pain in the knee region. Among participants with 50 years or older, the data were statistically significant for the wrist/hands and feet anatomical regions. The association between pain and stress in the wrist/hands regions was stronger for servants with working period equal or longer than 10 years in the university.

A multivariable analysis was conducted between the level of stress and pain considering the gender, age group, position (teacher or administrative technician) and time of work in the institution (data not presented). However, the association remained statistically significant.

Figure 1 shows the distribution of participants in accordance with the frequency (in quartiles) of musculoskeletal symptoms in last

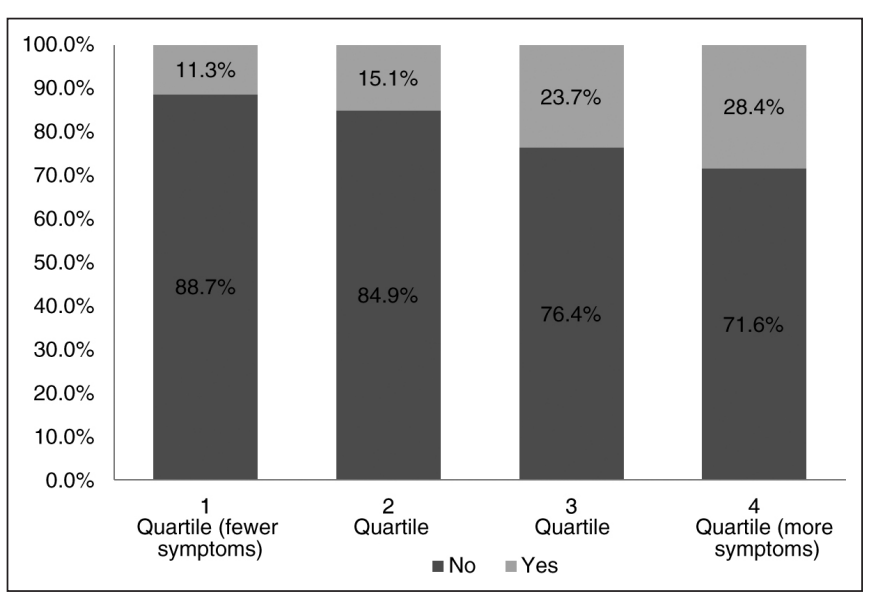

Figure 1. Distribution of the perceived stress in accordance with the musculoskeletal symptoms (in quartiles) in last the 12 months between teachers and technicians of the Federal University of Rio Grande, $(\mathrm{n}=717)$. Fisher's Exact test 0.001 the 12 months and the presence of the perceived stress between teachers and technicians of the university. It was observed that the higher the frequency of musculoskeletal symptoms, the higher the prevalence of the perceived stress among the participants.

\section{DISCUSSION}

It was found that most of the participants in the study reported musculoskeletal symptoms in at least one region assessed in the last year $(85.6 \%)$, being slightly less frequent concerning the last seven days $(70.4 \%)$. However, it is important to highlight the high number of servants with musculoskeletal complaints. The back region was the most prevalent in terms of pain symptoms in the last 12 months, $55.7 \%$ in the lower back and $54.1 \%$ in the upper part. When the perceived stress variable was analyzed, it was observed that the higher the stress score, the higher the prevalence of musculoskeletal symptoms (92.5\%), while the group with the lowest stress level had $81.9 \%$ rate. These differences were observed for almost all the anatomical regions analyzed. With respect to the involvement of musculoskeletal symptoms in teachers' population, some studies addressing this subject were conducted in Brazil with percentages ranging from 40.9 and $90.4 \%{ }^{12}$. These are numbers similar to those found in the present study, showing that $85.6 \%$ of the sample of the University staff reported some musculoskeletal symptom last year. Even the number being slightly smaller concerning the last seven days $(70.4 \%)$, it was still noted a high prevalence. Almost half of the servants had some kind of impairment in their activities as a result of these symptoms in at least one region (45.7\%), and more than half had to seek a health professional due to this pain $(58.0 \%)$. These numbers translate the high negative impact of musculoskeletal pain in the studied population, and they are corroborated by the literature $e^{1,2,18,29}$.

Chronic diseases that have musculoskeletal relation are one of the major health problems in Brazil in the productive phase of life $^{23}$. Musculoskeletal diseases are pointed as frequent causes of retirement and disability in the country ${ }^{24}$. Statistics of the $\mathrm{Na}$ tional Institute of Social Security (INSS) indicate an increase in benefits granted, including sick pay, besides being the second major cause of leave of absence ${ }^{14}$. The incidence is higher among the young (20 to 39 years old) and the women ${ }^{25}$. Available data indicate that more than $80 \%$ of the diagnostic of these disorders have resulted in accident allowance and disability retirement by the INSS ${ }^{26}$. 
Servants of the FURG presented a higher prevalence of musculoskeletal symptoms in the lumbar region, being the major cause to seek health care $(29.0 \%)$ or limitation in the performance of activities $(22.2 \%)$, regardless the studied period - last 12 months $(55.7 \%)$ or seven days $(33.2 \%)$. These results are corroborated by other studies with university teachers or basic education teachers, which indicated rates of $63.1^{27}$ and $51.5 \%{ }^{14}$.

For the technicians, studies point the prevalence of musculoskeletal pain or discomfort among nursing workers, $96.3 \%$ in last 12 months and $73.1 \%$ in the last seven days, being more frequent the symptoms in the back region $(71.5 \%)$, neck $(68 \%)$ and shoulders $(62.3 \%)^{26}$. In another study with public servants working on hospital cleaning and hygiene, in the last 12 months, $87 \%$ of the sample reported some symptom and half of the workers indicated the shoulders as the part of the body most involved in musculoskeletal symptoms ${ }^{28}$.

Still, in one study with office workers of a public university in Minas Gerais, 39.3\% reported localized pain, being the back region, shoulders, forearms a, $d$ hands the most cited sites ${ }^{29}$. It was possible to observe that the back region was cited as the cause of symptoms in these servants analyzed in the present study. Moreover, more than two thirds of the employees had musculoskeletal symptoms in the last 12 months and/or in the prior week, in accordance with the data of the Brazilian population where, according to the National Health Research of 2013, chronic backbone diseases registered a prevalence of $18.5 \%$ among adults, that is, almost one fifth of the Brazilian population ${ }^{23}$. The high percentage of reports of musculoskeletal symptoms signals a serious health problem in the studied population, consonant with the literature ${ }^{18,23,29}$.

As for the association between stress and musculoskeletal pain in public servants of the studied sample, it was observed that the higher the perceived stress, the higher the prevalence of musculoskeletal symptoms. It was also observed a linear association with statistical significance in almost all areas of the body, except the hip ( $\mathrm{p}=0.12$ ). It is important to consider the emotional and psychological factors involved with the work, the psychosocial factors related to the work organization, the individual psychological factors like repetitive, monotonous tasks, work overload, lack of autonomy, low job satisfaction, and low social support $\mathrm{t}^{30}$. These factors are singled out as indicators of stress and association with musculoskeletal problems ${ }^{30}$.

In relation to the trend observed in the sample, it stands out the stronger association among workers in terms of symptoms in the neck and the lower back, while the teachers showed a significant trend only for the knee region, contradicting previous studies that point the back, cervical, and upper limbs ${ }^{31}$. Among participants with 50 years or older, the data were statistically significant for the wrist/hands and feet. Yet, the association between pain and stress in the wrist/hands was stronger in servants with a working period equal to or longer than 10 years in the university. This period is lower than the one reported by Sanchez et al. ${ }^{31}$ that presented in their study that among the occupational risk factors in the involvement of the musculoskeletal system among teachers is a period longer than 15 years. Among the causes cited for the increased risk are: little or no time to rest between classes, lack of a specific place to rest, bad remuneration, a high number of students, inadequate body posture, job dissatisfaction, conflict with students ${ }^{31}$. It is worth mentioning that these causes impact mental health and act as a trigger of stress to teachers ${ }^{18,27,32}$.

The experience of pain sensation is known as a cortical function. The nerve impulse travels in the spinal cord up to the basal part of the brain, where it makes the second synapsis. The signals can go directly to the cortex or stimulate the autonomic nervous system (ANS). The nociceptive stimuli are also directed to the limbic system (amygdala), that defines the affective characteristic of pain. The stimulation finally reaches the posterior parietal area, where the integration of the nociceptive neural network happens, leading to the perception (interpretation) of pain $^{33,34}$. Acute pain usually occurs right after a trauma to the soft tissues or by inflammation, when inflammatory mediators are released, being related to an adaptation of the body to protect and facilitate tissue repair and healing ${ }^{5,34}$. Therefore, acute pain is a symptom that is rarely the cause to seek medical care ${ }^{35}$. On the other hand, chronic pain, without known pathological source, can be the consequence of changes in the functioning of the biological stress systems, resulting in abnormal pain perception. The main hypothesis suggests that the disruptions in the hypothalamic-pituitary-adrenal axis, the immune system, and the ANS contribute to the onset of chronic pain. This can occur by means of central sensitization, a process of hypersensitization of the neural nociceptive pathways ${ }^{36}$.

However, other authors suggest that the well-documented association between occupational stress and musculoskeletal pain is not fully explained by a stress effect on pain report. Moreover, it seems that the workers who report musculoskeletal pain are more prone to develop subsequent perceptions of stress. This can occur because pain makes people less tolerant to work psychological demands ${ }^{37}$.

In this way, stress can also be a consequence of the musculoskeletal pain. Any painful stimulation can activate the sympathetic nervous system and the hypothalamic-pituitary-adrenal axis, which constitutes the regulating axis of the stress reaction ${ }^{38}$.

Among the limitations of the present study, it is observed that when considering only the active servants performing their profession, we could have had the presence of underestimated data in terms of the prevalence of musculoskeletal pain. Probably, those with more serious symptoms of pain and/or stress are on a leave of absence or have refused to participate in the study. Therefore, the low participation (36.6\%) of the institution's employees may have underestimated the occurrence of both pain and stress as well as the association measures. However, all the servants of the institution, active in the period, were invited to participate in the study with the purpose to not generate a biased sample. The non-discrimination between chronic and acute pain is pointed as another limitation of the study. The tool used, although standardized and validated, does not make this distinction. Therefore, we can only talk about pain knowing that it can be chronic or acute.

As strengths of this study, it is the use of questionnaires validated in the country and translated to Portuguese, as well as the practical and economical way of application. 


\section{CONCLUSION}

The analysis of the results of the present study provided better visualization of the musculoskeletal symptoms picture in the civil servants of the university and its association with the perceived stress. This knowledge will be valid for the action plan to improve the quality of life of these individuals and, to contribute to understanding the health condition this class of workers in the country.

\section{ACKNOWLEDGMENTS}

Samuel de Carvalho Dumith is scholarship holder for research productivity from CNPQ. Leticia Maria da Silva Almeida is scientific initiation scholarship from CNPq.

\section{REFERENCES}

1. Martinez JE, Pereira GA, Ribeiro LG, Nunes R, Ilias D, Navarro LG. Study of self-medication for musculoskeletal pain among nursing and medicine students at Pontifícia Universidade Católica - São Paulo. Rev Bras Reumatol. 2014;54(2):90-4. English, Portuguese

2. Silva CD, Ferraz GC, Souza LA, Cruz LV, Stival MM, Pereira LV. Prevalência de dor crônica em estudantes universitários de enfermagem. Texto Contexto Enferm. 2011;20(3):519-25.

3. Tsang A, Von Korff M, Lee S, Alonso J, Karam E, Angermeyer MC, et al. Common chronic pain conditions in developed and developing countries: gender and age differences and comorbidity with depression-anxiety disorders. J Pain. 2008;9(10):883-91.

4. Breivik H, Collett B, Ventafridda V, Cohen R, Gallacher D. Survey of chronic pain in Europe: Prevalence, impact on daily life, and treatment. Eur J Pain. 2006;10(4):287-333.

5. Klaumann PR, Wouk AF, Sillas T. Patofisiologia da dor. Arch Vet Sci. 2008;13(1):1-12.

6. Malchaire J, Cock N, Vergracht S. Review of the factors associated with musculoskeletal problems in epidemiological studies. Int Arch Occup Environ Health. 2001;74(2):79-90.

7. Cardoso JP, Araújo TM, Carvalho FM, Oliveira NF, Reis EJ. [Psychosocial work-related factors and Musculoskeletal pain among school teachers]. Cad Saude Publica. 2011;27(8):1498-506. Portuguese.

8. Cardoso JP, Ribeiro IQ, Araújo TM, Carvalho FM, Reis EJ. Prevalência de dor musculoesquelética em professores. Rev Bras Epidemiol. 2009;12(4):604-14.

9. Lindenberg SI, Rosvall M, Choi B, Canivet C, Isacsson SO, Karasek R, et al. Psychosocial working conditions and exhaustion in a working population sample of Swedish middle-aged men and women. Eur J Public Health. 2010;21(2):190-6.

10. Moen BE, Wieslander G, Bakke JV, Norbäck D. Subjective health complaints and psychosocial work environment among university personnel. Occup Med. 2013;63(1):38-44.

11. Farias SM, Teixeira OL, Moreira W, Oliveira MA, Pereira MO. [Characterization of the physical symptoms of stress in the emergency health care team]. Rev Esc Enferm USP. 2011;45(3):722-9. Portuguese.

12. Fernandes MH, da Rocha VM, da Costa-Oliveira AG. [Factors associated with teachers' osteomuscular symptom prevalence]. Rev Salud Publica. 2009;11(2):256-67.

13. Fernandes MH, da Rocha VM, Fagundes AA. [Impact of osteomuscular symptoms on the quality of life of teachers]. Rev Bras Epidemiol. 2011;14(2):276-84. Portuguese.

14. Mango MS, Carilho MK, Drabovski B, Joucoski E, Garcia MC, Gomes AR. Análise dos sintomas osteomusculares de professores do ensino fundamental em Matinhos. Fisioter Mov. 2012;25(4):785-94.
15. Fonseca RM, Carlotto MS. Saúde Mental e Afastamento do Trabalho em Servidores do Judiciário do Estado do Rio Grande do Sul. Psicol Pesq. 2011;5(2):117-25.

16. Aguiar GA, Oliveira JR. Absenteísmo: suas principais causas e consequências em uma empresa do ramo de saúde. Rev Ciências Gerenciais. 2009;XIII(18):95-113.

17. de Cássia Pereira Fernandes R, da Silva Pataro SM, de Carvalho RB, Burdorf A. The concurrence of musculoskeletal pain and associated work-related factors: a cross sectional study. BMC Public Health. 2016;16:628-37.

18. Assunção AA, Abreu MN. [Factor associated with self-reported work-related Musculoskeletal disorders in Brazilian adults]. Rev Saude Publica. 2017;51(Suppl1):10s.

19. Kuorinka I, Jonsson B, Kilbom A, Vinterberg H, Biering-Sørensen F, Andersson G, et al. Standardised Nordic questionnaires for the analysis of musculoskeletal symptoms. Appl Ergon. 1987;18(3):233-7.

20. Pinheiro FA, Troccoli BT, Carvalho CV. [Validity of the Nordic Musculoskeletal Questionnaire as morbidity measurement tool]. Rev Saude Publica. 2002;36(3):30712. Portuguese.

21. Luft CD, Sanches Sde O, Mazo GZ, Andrade A. [Brazilian version of the Perceived Stress Scale: translation and validation for the elderly]. Rev Saude Publica. 2007;41(4):606-15. Portuguese.

22. Cohen S, Kamarck T, Mermelstein R. A global measure of perceived stress. J Health Soc Behav. 1983;24(4):385-96.

23. Oliveira MM, Andrade SS, Souza CA, Ponte JN, Szwarcwald CL, Malta DC. Problema crônico de coluna e diagnóstico de distúrbios osteomusculares relacionados ao trabalho (DORT) autorreferidos no Brasil: Pesquisa Nacional de Saúde, 2013. Epidemiol Serv Saúde. 2015;24(2):287-96

24. Almeida GF, Ribeiro MH, Silva MA, Branco RC, Pinheiro FC, Nascimento MD. Patologias osteomusculares como causa de aposentadoria por invalidez em servidores públicos do município de Sáo Luiz, Maranhão. Rev Bras Med Trab. 2016;14(1):37-44.

25. Walsh IA, Corral S, Franco RN, Canetti EE, Alem ME, Coury HJ. [Work ability of subjects with chronic musculoskeletal disorders]. Rev Saude Publica. 2004;38(2):149 56. Portuguese.

26. Magnago TS, Lisboa MT, Griep RH, Kirchhof AL, Camponogara S, Nonnenmacher CQ, et al. Condiçōes de trabalho, características sociodemográficas e distúrbios musculoesqueléticos em trabalhadores de enfermagem. Acta Paul Enferm. 2010;23(2):187-93.

27. Carvalho AJ, Alexandre NM. Sintomas osteomusculares em professores do ensino fundamental. Rev Bras Fisioter. 2006;10(1):35-41.

28. Martarello Nde A, Benatti MC. [Quality of life and Musculoskeletal symptoms in hospital housekeeping workers]. Rev Esc Enferm USP. 2009;43(2):422-8. Portuguese.

29. Silva CD, Juvêncio JF. Diagnosis of health-related physical fitness in office workers of the Federal University of Viçosa. Rev Bras Cineantropom Desempenho Humano. 2004;6(1):63-71.

30. Scopel J, Oliveira PA. Prevalência de sintomas osteomusculares, postura e sobrecarga de trabalho em cirurgiōes-dentistas. Rev Bras Med Trab. 2011;9(1):26-32.

31. Sanchez HM, Gusatti N, Sanchez EG, Barbosa MA. Incidência de dor musculoesquelética em docentes do ensino superior. Rev Bras Med Trab. 2013;11(2):66-75.

32. Neupane S, Nygård CH. Physical and mental strain at work: Relationships with onset and persistent of multi-site pain in a four-year follow up. Int J Industr Ergon. 2017;60(1):47-52.

33. Guimarães MA. A influência de um programa de ginástica laboral sobre a diminuição da intensidade da dor corporal. Rev Bras Prescr Fisiol Exerc. 2008;2(7):69-80.

34. Hall JE. Guyton \& Hall: Tratado de Fisiologia Médica. 12a ed. Rio de Janeiro: Elsevier; 2011.

35. Teixeira MJ, Teixeira WG, Santos FP, Andrade DC, Bezerra SL, Figueiró JB, et al. Epidemiologia clínica da dor musculoesquelética. Rev Med. 2001;80(ed esp pt.1):1-21.

36. Generaal E, Vogelzangs N, Macfarlane GJ, Geenen R, Smit JH, de Geus EJ, et al. Biological stress systems, adverse life events and the onset of chronic multisite musculoskeletal pain: a 6-year cohort study. Ann Rheum Dis. 2016;75(5):847-54.

37. Bonzini MM, Bertu L, Veronesi G, Ferrario MM, Conti M, Coggon D, et al. Is musculoskeletal pain a consequence or a cause of occupational stress? A longitudinal study. Arch Occup Environ Health. 2015;88(5):607-12.

38. Ferreira EA, Marques AP, Matsutani LA, Vasconcellos EG, Mendonça LL. Avaliaçăo da dor e estresse em pacientes com fibromialgia. Rev Bras Reumatol. 2002;42(2):104-10. 